\title{
Omówienie książki Dominiki Dudek i Marii Mazurek Nie tylko mózg. Opowieść psychiatry o ludzkim umyśle
}

Nie tylko mózg. Opowieść psychiatry o ludzkim umyśle (Wydawnictwo Mando, Kraków 2020) to książka doskonałego duetu składającego się z wybitnej przedstawicielki polskiej psychiatrii Dominiki Dudek oraz znakomitej dziennikarki Marii Mazurek specjalizującej się w tekstach popularnonaukowych. W jedenastu rozdziałach omówione zostały kluczowe problemy współczesnej psychiatrii, ubarwione niezwykle celnymi refleksjami praktykującej psychiatry, dysponującej wielką wiedzą i doświadczeniem badawczym.

Rozdział o psychiatrii i psychiatrach wskazuje na oryginalność psychiatrii jako dziedziny medycyny i dowodzi, że nauka ta wykracza poza ramy medycyny. Składa się na to wiele przyczyn, a wśród nich pewna niedookreśloność diagnostyki oraz osadzenie rozpoznania, a zwłaszcza terapii, w kontekście psychospołecznym. Wspomniane są również zbrodnicze praktyki eugeniczne i wykorzystywanie psychiatrii do celów politycznych, niespotykane w innych dziedzinach medycyny. Co do leczenia - autorki opisały różnorodne, często dość makabryczne próby interwencji podejmowane na przestrzeni wieków, a dotyczące chorych psychicznie. Na szczęście dożyliśmy czasów, gdy wprowadzenie w ostatnich 70 latach skutecznych leków psychotropowych w istotny sposób przybliżyło psychiatrię do niezabiegowych specjalności medycznych.

W rozdziale o umyśle i psychoterapii omówiono ten problem w duchu przezwyciężenia dualizmu kartezjańskiego, czyli uznania jedności czynności psychicznych (duszy) i czynności mózgu jako struktury cielesnej. Wiedział o tym już Freud, który napisał projekt naukowej psychologii, spopularyzowany dopiero długo po jego śmierci. W jego późniejszych koncepcjach, zwłaszcza psychoterapeutycznych, pobrzmiewa możliwość wpływu kontaktu na poziomie czysto poznawczym na czynność mózgu. Współcześnie wyartykułował to wspomniany w książce laureat Nagrody Nobla z 2000 r. Eric Kandel w manifeście opublikowanym dwa lata wcześniej na łamach „American Journal of Psychiatry”. Nagrodę Nobla, jak podano w książce, otrzymał za pionierskie badania pamięci, które przeprowadzał na ślimakach morskich. Wyniki można było jednak bezpośrednio przenieść na człowieka, co wskazuje na ich wielką uniwersalność. Autorki nazwały Kandela wiedeńczykiem z pochodzenia, aczkolwiek jego rodzice wywodzili się z polskich kresów wschodnich. Gdy rozmawiałem z nim na konferencji naukowej w 2005 r., chętnie przyznawał się do swoich polskich prakorzeni.

Wracając jeszcze do Freuda, podkreślane są jego wizjonerskie koncepcje na temat znaczenia nieświadomości oraz okresu dzieciństwa dla dalszego rozwoju psychicznego i zaburzeń psychicznych $\mathrm{w}$ wieku dorosłym. Teorie te są ostatnio często potwierdzane w badaniach neurobiologicznych i psychiatrycznych opartych na dowodach.

Rozdział o miłości i związkach podejmuje wiele ciekawych zagadnień. Jednym z nich jest odróżnienie zakochania od miłości. Omawiając neurobiologię zakochania, warto w grupie fenyloetyloamin wyraźnie wskazać na dominującą rolę dopaminy. W sposób adekwatny potraktowana została kwestia zachowania seksualnego mężczyzn i kobiet w kontekście ewolucyjnym, ale też kulturowym. Analizowane jest również bardzo często pomijane zagadnienie seksu u pacjentów psychiatrycznych. Rozdział kończy temat przemocy w rodzinie i tzw. syndromu sztokholmskiego.

W rozdziale o smutku i depresji autorki wskazują kryteria diagnostyczne, które pozwalają odróżnić depresję od normalnego smutku i rozpoznać ją jako chorobę wymagającą interwencji terapeutycznej. Leczenie depresji przedstawione jest w kontekście formuły ABCD, gdzie każda z liter oznacza czynniki związane z nieoptymalnymi efektami takiego leczenia: A - adekwatność terapii, B - behawioralne czynniki podtrzymujące chorobę, C - compliance (współpraca), D - diagnoza. W epilogu pojawia się problem samobójstwa, a autorki pointują, że depresja może być chorobą śmiertelną i taką jest w niemal jednej piątej przypadków.

Jeżeli książkę piszą dwie kobiety, nie może zabraknąć „feministycznych” wątków. Rozdział o współczesnych kobietach prezentuje nowoczesne poglądy dotyczące różnic między mózgiem kobiety i mężczyzny, jak również kulturowego schematu kobiecości. Wiele zaburzeń psychicznych wykazuje odrębność w zależności od płci. U kobiet częściej występuje depresja i znacznie częściej zaburzenia odżywiania. Rzadziej natomiast pojawiają się uzależnienia, ale jeżeli wystąpią, mają zwykle gorszy przebieg niż u mężczyzn. W skład typowo „kobiecej” psychiatrii wchodzą też 
zaburzenia związane z ciążą i porodem, które omówione zostały zarówno w kontekście najnowszej wiedzy, jak i własnych doświadczeń autorek.

W rozdziale o starości ten okres życia człowieka postrzegany jest przez autorki jako bardziej lub mniej odpowiednie przedłużenie dotychczasowej egzystencji. Jak błyskotliwie stwierdza psychiatra: „starość może być udana tylko wtedy, jeżeli postaramy się, by jak najmniej różniła się od młodości” (jest to zresztą tylko jeden z licznych bon motów). I przytacza przykład nieodżałowanej pamięci prof. Jerzego Vetulaniego, który zginął tragicznie w wieku 81 lat, funkcjonując jak osoba o co najmniej 30 lat młodsza. Autorki podkreślają, że ważne jest, by w wieku podeszłym nie rezygnować $z$ wszechstronnej aktywności, w tym, jeśli to możliwe, zawodowej. Omawiane są też zaburzenia psychiczne wieku matuzalowego, ze szczególnym uwzględnieniem postępującego otępienia. Dyskutowane są wielkie dylematy dotyczące zarówno pacjenta, jak i jego rodziny, na którą spada wielki ciężar opieki.

W rozdziale o naturze zła rozpatrywane są jego determinanty indywidualne i społeczne. Ciemna strona osobowości każdego z nas jest przywoływana poprzez opis eksperymentów Zimbardo i Milgrama. Ujęto też przypuszczenia na temat możliwych struktur mózgowych związanych ze „złem” i pow rót do pojęcia „psychopatii”. Rozdział kończą rozważania na temat odpowiedzialności za dokonane przewinienia w kontekście psychiatrycznym.

Rozdział o religijności zaczyna się od motywów religijnych w chorobach psychicznych, nadal częstych w zaburzeniach psychotycznych i obsesyjno-kompulsyjnych. Do tej pory funkcjonują dwie formy leczenia tych zaburzeń - u psychiatry i za pomocą egzorcyzmów. Te dwa różne sposoby terapii wynikają $z$ dwóch teoretycznych założeń patogenezy $-\mathrm{z}$ jednej strony zaburzenia czynności mózgu, z drugiej dominacja złych duchów. To drugie, często formułowane jako konszachty z diabłem, stanowiło podstawę wielkich zbrodni inkwizycji popełnianych przez Kościół. Przytaczana jest też pozytywna strona religijności, która u niektórych pacjentów pozwala wzmocnić siły prowadzące do zdrowienia. Wspomniano również problem zaburzeń psychicznych u duchownych, co w części ma związek z celibatem.

W rozdziale o fobiach, natręctwach i lęku omówiono patogenezę w kontekście ewolucyjnym i kulturowym, a także istotne przejawy tych psychiatrycznych jednostek diagnostycznych. Opisano również związek między zaburzeniami lękowymi a dolegliwościami somatycznymi, w tym zjawisko somatyzacji. W zakończeniu przedstawiony jest kliniczny obszar interdyscyplinarny obejmujący psychiatrię oraz inne dziedziny medycyny.

Ostatnie dwa rozdziały poświęcone są tzw. dużej psychiatrii. Pierwszy z nich traktuje o chorych na schizofrenię, czyli zgodnie z definicją Antoniego Kępińskiego o pacjentach, „którzy więcej czują". W obrazowy sposób opisywane są spektakularne objawy tej choroby, takie jak urojenia i omamy. U niektórych pacjentów początek choroby może być trudny do identyfikacji. Przywołane jest zjawisko zwane paragnomenem, opisane przez krakowskiego psychiatrę i neurologa prof. Eugeniusza Brzezickiego. Polega ono na tym, że na kilka lat przed pojawieniem się choroby występuje epizod dziwacznego i niezrozumiałego zachowania. W rozdziale wspomniana jest również możliwość inicjacji schizofrenii poprzez zażywanie środków psychoaktywnych oraz fakt krótszego życia chorych na schizofrenię z różnych przyczyn zdrowotnych i społecznych, w tym z powodu samobójstwa (10\%).

Rozdział o kreatywności i dwóch biegunach dotyczy choroby afektywnej dwubiegunowej (ChAD). Dominika Dudek jako wybitna specjalistka w tej dziedzinie zostawiła ten temat na deser. Barwnie opisywany jest stan manii oraz depresji w tej chorobie. Depresja w przebiegu ChAD w porównaniu z depresją nawracającą wykazuje nieznaczne odrębności kliniczne i znaczne terapeutyczne. Głównie w takim stanie istnieje możliwość diagnozy i leczenia pacjenta w warunkach ambulatoryjnych. Od dawna wiadomo o nadreprezentacji osób z cechami dwubiegunowości wśród artystów, pisarzy i malarzy wykazujących się genialną kreatywnością. W książce wymieniono nazwiska twórców z ostatnich lat, które można by mnożyć, dołączając do nich Robina Williamsa czy Wojciecha Młynarskiego. Związek między chorobami psychicznymi a kreatywnością może być elementem pozytywnej strony tych zaburzeń, jednak nie zwalnia to od konieczności interwencji psychiatrycznej w sytuacjach, które tego wymagają. Moim zdaniem samobójstwo Robina Williamsa w drugiej dekadzie XXI w. kładzie się cieniem na wizerunku psychiatrii amerykańskiej. 
Podsumowując - książka Nie tylko mózg. Opowieść psychiatry o ludzkim umyśle winna stanowić obowiązkową lekturę dla wszystkich psychiatrów i psychologów, jak również każdego, kto w jakimkolwiek stopniu interesuje się osiągnięciami neuronauki (neuroscience).

$\mathrm{Z}$ wybitną przedstawicielką polskiej psychiatrii z autorskiego duetu od ponad dwóch dekad łączy mnie wspaniała relacja naukowa i osobista, z wieloma jej poglądami oraz stwierdzeniami mogę się całkowicie identyfikować.

prof. Janusz Rybakowski Uniwersytet Medyczny w Poznaniu e-mail: janusz.rybakowski@gmail.com 